\title{
Manajemen Pendidikan Karakter dalam Menumbuhkan Sikap Religius Peserta Didik MI Mafatihul Akhlaq Jepara
}

\author{
Elya Umi Hanik \\ Institut Agama Islam Negeri Kudus, Kudus, Indonesia \\ elyaumi@iainkudus.ac.id \\ Eva Luthfi Fakhru Ahsani \\ Institut Agama Islam Negeri Kudus, Kudus, Indonesia \\ evaluthfi@iainkudus.ac.id
}

\begin{abstract}
This study aims to analyze the management of character education in growing the religious character of students at MI Mafatihul Akhlaq Jepara. This research is a field research with a qualitative method approach. The object of this research is MI Mafatihul Akhlaq Demangan, Tahunan, Jepara. This research data collection using interview techniques, observation and documentation, technical data analysis through the stages of data collection, data reduction, data presentation and classification and validity test using data triangulation techniques. The results of this study include; 1) the character education management model implanted at MI Mafatihul Akhlaq Jepara includes the process of planning, organizing, implementing and evaluating it, religious character, honesty, intelligence, and caring for others. Teachers have strategies to support the achievement of the concept of character education management. 2) Strategies in implementing character education in fostering the religious attitude of students through example, learning, empowerment and civilizing, strengthening, and assessment.
\end{abstract}

Keywords: Management Model, Character Education, Religious Attitud 
Penelitian ini bertujuan untuk menganalisis manajemen pendidikan karakter dalam menumbuhkan sikap religius peserta didik di MI Mafatihul Akhlaq Jepara. Penelitian ini merupakan penelitian lapangan (field research) dengan pendekatan metode kualitatif. Objek penelitian ini di MI Mafatihul Akhlaq Demangan, Tahunan, Jepara. Pengumpulan data penelitian ini dengan menggunakan teknik wawancara, observasi dan dokumentasi, teknis analisi data memalaui tahapan pengumpulan data, reduksi data, penyajian data dan klasifikasi serta uji keabsahan menggunakan Teknik triangulasi data. Hasil penelitian ini meliputi; 1)model manajemen pendidikan karakter yang ditanamkan di MI Mafatihul Akhlaq Jepara meliputi proses perencanaan, pengorganisasian, pelaksanaan serta evaluasinya, karakter religius, kejujuran, cerdas, dan peduli terhadap sesama. Guru memiliki strategi dalam menunjang tercapainya konsep manajemen pendidikan karakter. 2)Strategi dalam mengimplementasikan pendidikan karakter dalam menumbuhkan sikap religus peserta didik melalui keteladanan, pembelajaran, pemberdayaan dan pembudayaan, penguatan, dan penilaian.

Kata kunci: Model Manajemen, Pendidikan Karakter, Sikap Religius

\section{A. Pendahuluan}

Investasi dalam bidang pendidikan sangat diperlukan dalam upaya menghasilkan sumber daya manusia yang berkualitas. Pendidikan dapat meningkatkan taraf hidup dan memungkinkan seseorang untuk dapat meningkatkan kemampuannya secara terencana. Perubahan jaman merupakan suatu keniscayaan yang selalu ada, karena kehidupan adalah perubahan, begitupun dalam dunia pendidikan yang selalu dinamis dan kompleks. Perubahan akan dikira sesuatu yang membahayakan dan menghawatirkan seseorang ketika orang tersebut tidak bisa mengimbanginya dengan latar belakang pendidikan yang baik. Pendidikan di negara kita saat ini sedang mengalami krisis karakter, ketika dunia pendidikan mengalami kemajuan dalam hal teknologi dan industri tetapi kehidupan moralnya sedang mengalami degradasi yang luar biasa. Pendidikan karakter mulai dibicarakan oleh masyarakat biasa maupun dalam dunia pendidikan sejak tahun 2009, banyak media, ahli pendidikan, ataupun tokoh masyarakat memberikan saran agar pendidikan karakter segera diberlakukan dalam dunia pendidikan. Karena pendidikan karakter digunakan sebagai landasan untuk mewujudkan visi pembangunan nasional, yaitu mewujudkan masyarakat yang berakhlak mulia, bermoral, beretika, berbudaya, dan beradab sesuai dengan pancasila (Sulistyowati, 2012). Pendidikan kaarkter di sekolah lebih banyak berurusan dengan penanaman nilai, pendidikan karakter agar dapat disebut sebagai integrasi dan utuh mesti juga menentukan metode yang akan dipakainya, sehingga tujuan pendidikan karakter itu akan semakin terarah dan efektif. Pendidikan karakter yang mengakarkan 
dirinya pada konteks sekolah akan mampu menjiwai dan mengarahkan sekolah pada penghayatan pendidikan karakter yang realistis, konsisten, dan integral (Koesoema, 2007). Oleh karena itu, untuk merencanakan dan mengembangkan karakter anak sangat dibutuhkan pendidikan yang berkualitas. Pendidikan yang dimaksud bukan hanya merupakan pendidikan formal yang didapat dari sekolaha, melainkan pendidikan dilingkungan keluarga sebagai upaya meningkatkan kulaitas anak dalam ilmu pengetahuan, keterampilan, dan karakternya. Pemerintah telah menetapkan tujuan pendidikan nasional yang dituangkan dalam Undang-Undang Nomor 20 Tahun 2003 tentang Sistem Pendidikan Nasional Bab II Pasal 3 sebagai berikut: "Pendidikan nasional berfungsi mengembangkan kemampuan dan membentuk watak serta peradaban bangsa yang bermartabat dalam rangka mencerdaskan kehidupan bangsa, bertujuan untuk mengembangkan potensi peserta didik agar menjadi manusia yang beriman dan bertakwa kepada Tuhan Yang Maha Esa, berakhlak mulia, sehat, berilmu, cakap, kreatif, mandiri, dan menjadi warga negara yang demokratis serta bertanggung jawab". Berdasarkan tujuan pendidikan nasional tersebut, pendidikan disekolah tidak hanya terkait upaya penguasaan dibidang akademik oleh peserta didik, namun harus diimbangi dengan pembentukan karakter perlu diperhatikan oleh pendidik di sekolah dan orang tua dirumah. Jika keseimbangan tersebut dilakuka, pendidikan dapat menjadi dasar untuk mengubah anak menjadi lebih berkualitas dari aspek kemanusiaan, ilmu pengetahuan, dan akhlak (Sani \& Kadri, 2016).

Mutu pendidikan di Indonesia pada dasarnya kurang menunjukkan peningkatan kualitas yang signifikan, bahkan cenderung menurun. Salah satu penyebabnya adalah menurunnya sikap dan perilaku moral yang dikehendaki, atau terjadinya degaradasi moral, degradasi moral merupakan penurunan tingkah laku manusia akibat tidak mengikuti hati nurani karena kurangnya kesadaran diri terhadap kewajiban mutlak(Saifuddin \& Hanik, 2020), untuk menginspirasi persoalan semacam itu, pendidikan perlu diperhatikan dengan serius misalnya dengan direkonstruksi ulang agar menghasilkan lulusan yang lebih berkualitas dan siap mengahadapi dunia masa depan yang penuh dengan problema dan tantangan serta dapat menghasilkan lulusan yang memiliki sikap dan perilaku moral yang mulia. Kemajuan ilmu pengetahuan dan teknologi yang dialami manusia sekarang ini tidak sedikit membawa dampak negatif terhadap sikap dan perilaku moral dan akhlak manusia itu sendiri, baik sebagai makhluk individu maupun sosial. Dampak negatif yang paling nyata terhadap kehidupan manusia atas kemajuan tersebut adalah mewabahnya budaya materi. Hal ini ditandai dengan meluasnya anggapan bahwa satu-satunya yang dapat membahagiakan manusia adalah kekayaan materi, sehingga mereka hanya mengejar materi tanpa menghiraukan nilainilai spiritual yang sangat berperan dalam memelihara dan mengendalikan perilaku atau 
Elya Umi Hanik dan Eva Luthfi Fakhru Ahsani

akhlak mereka. Padahal nilai spiritual yang berfungsi membina kepribadian manusia dalam kedudukannya sebagai hamba Allah SWT dan masyarakat(Supadie, 2015).

Pelaksanaan pendidikan karakter sebenarnya menyangkut keseluruhan komponen pendidikan, mulai dari pemerintah sebagai pengambil kebijakan sistem pendidikan nasional, manajerial kepala sekolah, kompetensi guru, sarana prasarana, kurikulum dan dukungan dari masyarakat.Agar terwujudnya pembentukan karakter yang diharapkan, maka perlu adanya manajemen untuk mengelola pendidikan karakter pada ranah yang sesuai khususnya pada peserta didik yang menjadi objek penanaman niai-nilai karakter dalam kehidupan sehari-hari sehingga terbentuk peserta didik yang berkarakter. Dengan manajemen Pendidikan karakter, diharapkan mampu menumbukan sikap religious peserta didik, dalam hal ini sikap religius dapat diartikan sebagai sikap dan perilaku yang patuh dalam melaksanakan ajaran agama yang dianutnya, toleran terhadap pelaksanaan ibadah agama lain, dan hidup rukun dengan pemeluk agama lain. Dari deskripsi ini dapat disimpulkan bahwa bila seseorang memiliki karakter religius, ia akan menjadi orang yang baik. Sebab orang yang religius bersikap taat dan patuh pada agamanya yang pasti mengajarkan kebaikan (Sultoni, 2013).

Kondisi riil di MI Mafatihul Akhlaq Jepara yang menjadi penelitian yaitu pelaksanaan kebiasaan bersalaman dengan setiap guru di pagi hari, memulai pelajaran dengan berdo'a dan dilanjut dengan membaca surat-surat pendek, melaksanakan sholat dzuhur berjamaah sebelum pulang sekolah, dan adat sopan santun, implementasi Pendidikan karakter juga tercermin pada pembelajaran setiap mata pelajaran di kelas. Sebagaimana hasil penelitian yang dilakukan oleh Muhammad Jamil dkk terdapat lima poin kunci mensukseskan program pendidikan karakter dianataranya; perencanaan, pelaksanaan, sikap ramah guru, dukungan stakeholder dan persiapan peserta didik (Jamil et al., 2021), strategi pembentukan karakter dengan faktor pendukung dari kepala sekolah yang melibatkan guru, komite sekolah serta pemangku kepentingan serta penyusunan RPP dalam pembelajaran (Abbas \& Muchlis, 2021), dan diperkuat oleh penelitian Suastika, bahwa kepala sekolah memiliki peran yang penting dalam pembentukan karakter, strategi kepala sekolah dalam penguatan pendidikan karakter diintegrasikan ke dalam kegiatan intrakurikuler dan ekstrakurikuler, serta memberikan pembiasaan di sekolah. implementasi strategi tersebut mengintegrasikan pendidikan karakter ke dalam setiap mata pelajaran atau tema dan muatan lokal; dan ke dalam kegiatan ekstrakurikuler di SD Negeri Mangasa Makasar dan Madrasah Ibtidayah Negeri 2 Makasar antara lain pramuka, dokter anak, drum band dengan memotivasi, memberi nasehat, pemberian hadiah, sanksi dan kesopanan; sehingga mengakibatkan kesadaran, aktivitas rutin, aktivitas spontan, dan pengkondisian.(Nurafiati et al., 2021) 
Berdasarkan pada permasalahan tersebut, peneliti memilih MI Mafatihul Akhlaq sebagai obyek penelitian. Alasannya karena madrasah ini memiliki komitmen untuk mengimplementasikan pendidikan karakter guna mewujudkan sikap religious peserta didik di MI Mafatihul Akhlaq yang terletak di Desa Demangan Kecamatan Tahunan Kabupaten Jepara. Madrasah ini mendidik dan melatih peserta didiknya untuk memiliki pengetahuan dan keterampilan pada bidang pengetahuan dan agama.

Penelitian ini termasuk penelitian lapangan (field research) dengan pendekatan metode kualitatif. Objek penelitian ini di MI Mafatihul Akhlaq Demangan, Tahunan, Jepara. Pengumpulan data penelitian ini dengan menggunakan teknik wawancara, observasi dan dokumentasi. Teknik analisis data menggunakan tehnik Triangulasi, yakni teknik pemeriksaan keabsahan data yang memanfaatkan sesuatu yang lain diluar data untuk keperluan pengecekan atau sebagai pembanding terhadap data itu artinya melakukan validasi, dengan cara mengecek dokumen program dan bukti tertulis lainnya.

\section{B. Pembahasan}

\section{Manajemen Pendidikan Karakter di MI Mafatihul Akhlaq Jepara}

Manajemen pendidikan merupakan suatu ilmu yang mempelajari bagaimana menata sumber daya untuk mencapai tujuan yang telah ditetapkan secara produktif dan bagaimana menciptakan suasana yang baik bagi manusia yang turut serta di dalam mencapai tujuan yang disepakati bersama (Suhelayant, 2020). Manajemen pendidikan karakter dikelola dengan baik mengikuti fungsi manajemen sebagai dasar pengelolaan pendidikan karakter, seorang guru membutuhkan kemampuan manajerial yang baik sehingga mampu mengakomodir seluruh kegiatan pendidikan karakter di sekolah, pendidikan karakter sejalan dengan proses pembelajaran, mengikuti berbagai kurikulum pendidikan yang ada di sekolah, pendidikan karakter menyatu dengan kegiatan proses pembelajaran, manajemen pendidikan karakter tersusun dengan baik bersama dengan kurikulum pendidikan, RPP, silabus, serta dapat diterapkan dalam berbagai mata pelajaran di sekolah. Penerapan manajemen pendidikan karakter di sekolah sangat penting untuk dilakukan, hal ini dapat memberikan efek yang positif terhadap perilaku dan kepribadian serta moral pelajar, membentuk akhlaq yang mulia dalam diri pelajar, sehingga dapat memicu diri pelajar untuk melaksanakan kegiatan pembelajaran sejalan dengan budi pekerti yang luhur, adanya penanaman budi pekerti yang luhur melalui pendidikan karakter memberikan peluang yang besar dalam upaya pencapaian prestasi belajar pelajar. Selain itu prilaku dan akhlaq yang positif dalam diri pelajar dapat mendorong pencapaian kegiatan proses pembelajaran di sekolah, proses pembelajaran akan lebih nyaman, tenteram dan dapat menimbulkan iklim belajar belajar yang positif 
di sekolah sehingga mampu menciptakan kualitas pendidikan yang tinggi di sekolah pula. Pencapaian kualitas pendidikan dan proses pembelajaran yang tinggi di sekolah memberikan pengaruh dalam pencapaian prestasi belajar pelajar dan secara tidak langsung adanya prilaku dan akhlaq yang baik dalam diri pelajar dapat memberikan pencapaian positif dalam peningkatan kualitas dan daya saing sekolah. (Hasibuan et al., 2018)

Manajemen pendidikan karakter merupakan pengelolaan tata nilai dan aktivitas pendidikan yang dijabarkan dalam tahap-tahap manajemen, yaitu perencanaan, pelaksanaan dan evaluasi. Manajemen, dalam konteks penelitian ini, merujuk pada standar pengelolaan satuan pendidikan. Pengembangan program kerja sekolah sejalan dengan tata nilai lembaga yang menaunginya, yaitu yayasan pondok pesantren. Keselarasan ini didasarkan pandangan bahwa pendidikan karakter merupakan bagian dari pendidikan akhlaq; ajaran Islam yang melandasi pemikiran dan tindakan akhlaq bersesuaian dengan Pancasila.(Rohman, 2019) Manajemen pendidikan membentuk karakter peserta didik, meliuputi tahap perencanaan yang berupa merencang beberapa hal seperti pembiasaan bersalaman dan mencium tangan setiap bertemu ibu dan bapak gurunya dipagi hari, membaca surat-surat pendek sebelum dimulainya pembelajaran, melaksanakan sholat dzuhur secara berjamaah, dan adat sopan santun. Segala tingkah laku Rasulullah SAW mengandung nilai-nilai moral yang bersendikan akhlakul karimah baik dalam sikap keseharian bahkan termasuk dalam etika berperangpun menggunakan tata cara dan nilai- nilai akhlakul karimah (Hefniy, 2017). Manajemen karakter yang diimplementasikan diharapkan mampu menumbuhkan sikap religius pesreta didik. Istilah religius meliputi (ketaatan)doktrin, sistem yang mengatur pemerintahan (iman) dan ritual kepada Tuhan Yang Maha Esa, serta urutan aturan yang berkaitan dengan interaksi manusia dan lingkungan. Artinya manusia kelak akan secara spontan dan mudah melakukan apa yang diinginkannya tanpa dandanan dan pertimbangan (perilaku baik dan buruk manusia). Singkatnya, perilaku religius tidak hanya terlihat saat seseorang melakukan ibadah, tetapi juga saat melakukan aktivitas berbasis kesuburan lainnya. Oleh karena itu, keberagaman seseorang akan mencakup semua aspek atau aspek. Religius merupakan apresiasi dan implementasi ajaran agama dalam kehidupan sehari-hari.(Zuhri \& Usman, 2021)

Manajemen pendidikan karakter pada peserta didik MI Mafatihul Akhlaq Jepara, tercermin pada kegiatan perencanaan, pengorganisaian, pelaksanaan dan evlauasi. 1) Kegaiatan perencanaan meliputi integrasi nilai- nilai Pendidikan karakter pada pembelajaran yang termuat pada RPP pada setiap mata pelajaran, penyusunan jadwal kegaiatan di luar kelas untuk menumbuhkan sikap religius, seperti; sholat duha, budaya $3 \mathrm{~S}$ senyum, sapa, salam, tahfidz quran juz 30, sholat duhur berjamaah serta 
pembacaan asmaul husna setebelum pembelajaran, kegiatan tersebut dilaksanakan melalui pembiasaan, keteladanan, dan pembinaan juga diintegrasikan kedalam kegiatan seluruh muatan pelajaran serta dalam kegiatan sehari-hari ketika dirumah. Selain itu setiap rencana pelaksanaan pembelajaran yang disusun oleh setiap guru mengintegrasikan nilai-nilai karakter di dalam pembelajaran, 2)kegiatan pengorganisasian meliputi; pembagian jadwal kegiatan keagamaan serta pembagian guru piket. 3) kegiatan pelaksanaan meliputi; melaksanakan semua kegaiatan yang sudah direncanakan di kegiatan awal perencanaan. 4)kegiatan pengawasan dan evaluasi dilaksanakan untuk mengontrol pelaksanaan Pendidikan karakter dan evaluasi dilaksanakan untuk melihat tingkat keberhasilan serta hambatan implementasi Pendidikan karakter dalam menumbuhkan sikap religus peserta didik.

Proses penanaman nilai dalam sebuah pendidikan karakter tidak terjadi secara vertikel sebagaiman diyakini kebanyakan orang selama ini, yaitu sebuah proses yang sifatnya searah dari guru menuju siswa. Pendidikan karakter berkaitan dengan sebagaimana nilai-nilai moral itu menjadi jiwa yang menghidupi sebuah komunitas. Oleh karena itu relasi pendidikan dalam proses pendidikan karakter bagi yang lain. Guru menjadi pelaku utama karena posisinya dalam relasi sosial kelembagaan menempatkan mereka sebagai sosok keteladanan. Untuk itu, kepercayaan bahwa setiap individu memiliki nilai-nilai baik yang ditularkan merupakan sebuah asumsi kultural yang diandaikan dalam sekolah yang bernafaskan pendidikan karakter (Koesoema, 2016). Penetapan nilai-nilai positif yang telah dirancang akan disampaikan kepada pihak yayasan dan komite sekolah dan juga bisa diterapkan saat melakukan rapat bersama sehingga bisa dijadikan sebagai pedoman bagi para guru dan warga madrasah dalam memangun karakter peserta didik yang efektif. Sehubungan guru merupakan peran elemen sekolah yang penting dalam sekolah maka guru harus berupaya melakukan tugas dalam pembentukan karakter peserta didik (Rahayuningtyas et al., 2021). Manajemen Pendidikan karakter dalam menumbuhkan sikap religius pada peserta didik pada MI Mafatihul Akhlaq Jepara, terbentuk melalui Moral knowing, Moral Feeling dan Moral Action. Moral knowing terbentuk dari penanaman Pendidikan karakter baik dalam pembelajaran di dalam kelas serta diluar Kelas, Moral Feeling menumbuhkam sikap empati, pengendalian diri , cinta kebaikan serta rasa percaya diri, dan moral action yang meliputi kompetensi, keinginan dan kebiasaan peserta didik di MI Mafatihul Akhlaq Jepara. 


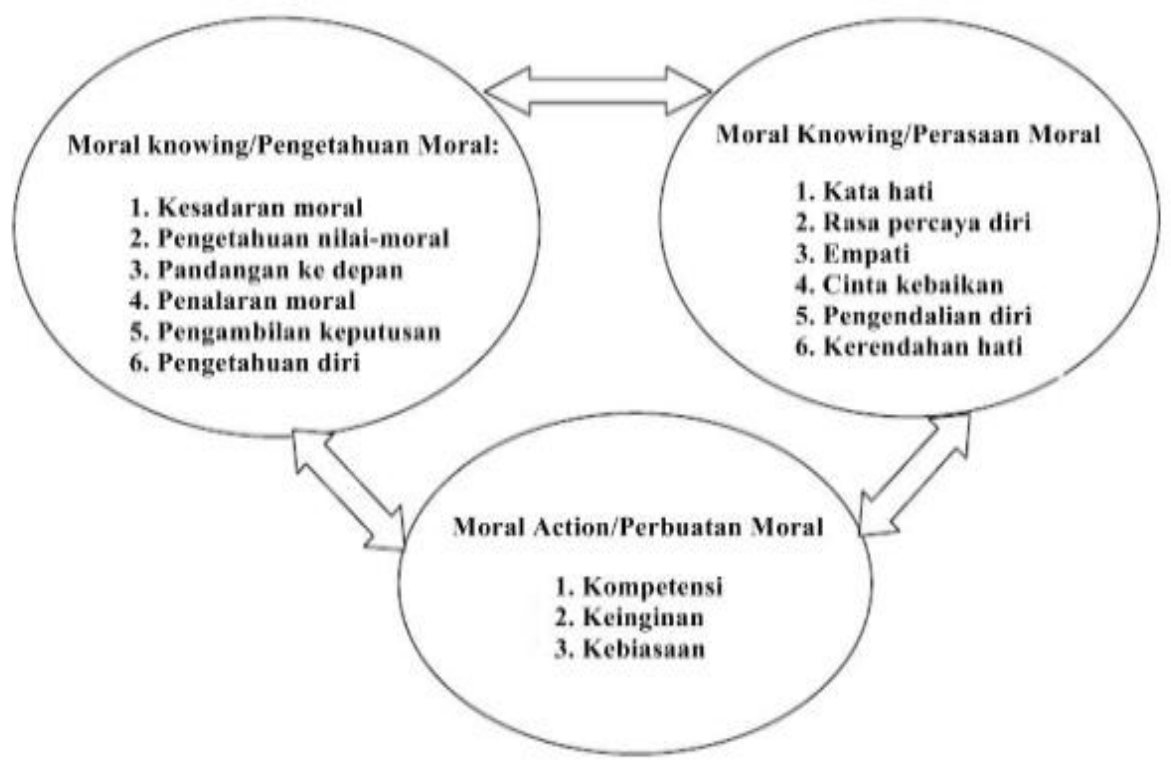

\section{Budaya Madrasah dalam Meningkatkan Kualitas Pendidikan}

Model pengajaran yang dilakukan setiap guru ada yang sama dan ada juga yang berbeda karena setiap guru memiliki cara-cara tersendiri dalam menangani masalah dalam penerapan pendidikan karakter ini. Hal ini sesuai dengan pendapat Mirna Amir dalam bukunya yaitu, cara belajar siswa yang berbeda memerlukan cara pendekatan pembelajaran yang berbeda. Guru harus mampu mempergunakan berbagai pendekatan agar anak tidak cepat bosan. Kepekaan dan daya sensitivan guru harus terus dilatih, agar kemampuan guru untuk melakukan berbagai pendekatan dalam belajar dapat ditingkatkan (Amir, 2011). Perilaku mengajar yang dipertunjukkan guru sangat beraneka ragam, meskipun maksudnya sama. Aneka ragam perilaku guru mengajar ini bila ditelusuri akan diperoleh gambaran tentang pola umum interaksi guru, isi atau bahan pelajaran, dan siswa (Kusumawati, Naniek \& Maruti, 2019). Melalui pemodelan, peserta didik benar-benar mampu melihat dan merasakan pengalaman yang menjadikannya terbiasa dengan hal-hal yang baik di lingkungan sekitarnya. Untuk dapat menggunakan strategi ini, ada dua syarat yang harus dipenuhi. Pertama, guru atau orang tua harus berperan sebagai model yang baik bagi murid-murid atau anak-anaknya. Kedua, anakanak harus meneladani orang-orang yang berakhlak mulia.

Model Pengajaran selanjutnya yang tampak di MI Mafatihul Akhlaq Jepara dicontohkan dalam kegiatan sehari-hari antar guru seperti saling menolong antar guru dan peserta didik, menjalin hubungan baik antara guru dengan peserta didik maupun guru dengan guru dan sesama peserta didik, cara guru menyelesaikan masalah dengan 
adil, menghargai pendapat peserta didiknya, berbicara dengan santun, kegiatan-kegiatan ini merupakan perilaku secara alami yang dijadikan model oleh anak-anak. Secara tidak sadar peserta didik akan meniru apa yang biasa mereka lihat setiap harinya.

Beberapa keterampilan yang harus dimiliki oleh peserta didik untuk mengamalkan nilai-nilai yang telah diajarkan tersebut yaitu salah satunya dengan mengembangkan keterampilan peserta didik dalam berkomunikasi yang baik. Selanjutnya yaitu keterampilan menyimak, dan berfikir secara kritis dan kreatif dalam menerima pembelajran karakter. Nilai dan pendidikan merupakan dua hal yang penting yang tidak dapat dipisahkan bahkan ketika pendidikan cenderung diperlakukan sebagai wahana transfer pengetahuan pun disana telah terjadi perambahan nilai yang bermuara pada nilai kebenaran intelektual. Pembentukan karakter dipengaruhi oleh beberapa kondisi lingkungan antara lain hubungan antara pribadi yang menyenangkan, keadaan emosi, metode pengasuhan, peran dini yang diberikan kepada anak, struktur keluarga dimasa kanak-kanak dan rangsangan terhadap lingkungan.

Pendidikan nilai karakter yang ingin dikembangkan di MI Mafatihul Akhlaq diantaranya yaitu membiasakan membaca surat-surat pendek/ Juz 30 setiap hari sebelum pembelajaran dimulai dan melaksanakan sholat dzuhur secara berjamaah. Menurut kepala sekolah MI Mafatihul Akhlaq Bapak MS menyebutkan bahwa kegiatan membaca surat-surat pendek ini bertujuan untuk supaya nantinya para alumni bisa dengan fasih dan hafal dari juz 30 ini, kegiatan ini dilaksanakan mulai dari kelas 1-6 dengan dibagi surat perkelas dari yang termudah, sedangkan untuk kegiatan sholat dzuhur berjamaah ini dimaksudkan agar para peserta didik selalu melaksanakan ibadah sholat tepat waktu dan dilaksanakan secara berjamaah agar nantinya ia terbiasa dengan hal ini sehingga meskipun sudah lulus kebiasaan ini tetap akan dibawa sampai kapanpun.

Menurut salah satu guru kelas yaitu Ibu LH menjelaskan bahwa dalam pelaksanaan kegiatan membaca surat-surat pendek dengan model membacanya secara bersama sama setiap hari hingga secara tidak sadar peserta didik akan hafal dengan sendirinya. Menurut siswa yang berinisial MFMW ia bercerita bahwa pada saat awal diterapkannya kegiatan tersebut merasa berat karena belum terbiasa tetapi dengan model penyampaian yang sudah dipaparkan oleh guru kelas tersebut maka ia bisa mengikuti dengan mudah secara perlahan-lahan dan mulai terbiasa. Sedangkan menurut orang tua/wali murid yang berinisial Ibu S menyebutkan bahwa senang dengan adanya kegiatan yang baik ini dan sangat berdampak baik kepada anaknya, krgiatan tersebut merupakan salah satu daya tarik dari MI Mafatihu Akhlaq itu sendiri. Semua peserta didik bisa melaksanakan kegiatan tersebut dengan baik dan bisa menjalankannya hingga 
ketika ia dirumah karena sudah terbiasa dilaksanakan disekolah, maka pembiasaan tersebut juga akan menular dikegiatan rumah juga.

Nilai-nilai karakter mulia itu dapat kita temukan dalam adat dan budaya di sekolah dengan melalui kegiatan pembiasaan. Lokalitas menjadi penting dikedepankan dalam pendidikan karakter, sehingga peserta didik tidak tercerabut dari akar dan budayanya. Ini artinya nilai-nilai luhur yang berasal dari adat dan budaya local hendaknya lebih diutamakan untuk diinternalisasikan kepada peserta didik melalui pendidikan karakter. Pendidikan karakter diarahkan pada nilai- nilai pembentukan budaya sekolah seperti sikap, pembiasaan sehari-hari serta simbol- simbol yang dilakukan oleh semua warga sekolah (Cahyani et al., 2021).

Pembiasaan-pembiasaan positif yang dikembangnkan di MI Mafatihul Akhlaq Jepara tidak hanya diperuntukkan bagi peserta didik saja, melainkan juga bagi para guru. Kegiatan tersebut dapat menuangkan dan mengimplementasikan semua yang sudah diajarkan kedalam bentuk perilaku yang baik sebagai akhlak yang mulia (Farida \& Kamalia, 2020). Guru juga harus ikut melakukan pembiasaan positif dengan tujuan agar para guru MI Mafatihul Akhlaq bisa menjadi teladan yang baik bagi peseta didiknya. Karen guru berperan membina peserta didik agar dapat memiliki kepribadian yang baik dan berakhlakul karimah (Zafi et al., 2021).

\section{Peran Guru Madrasah dalam Menumbuhkan Karakter Peserta Didik}

Pelaksanaan pembentukan karakter peserta didik di MI Mafatihul Akhlaq Jepara membutuhkan waktu dan juga komitmen dari guru madrasah, yaitu dari para guru untuk mendidik anak menjadi priadi yang berkarakter sesuai dengan apa yang ingin dicapai. Melalui ketaatan, kesabaran, dan keikhlasan dari para guru di MI Mafatihul Akhlaq Jepara terhadap proses pendidikan karakter dan moral ini dampaknya bukan hanya kepada peserta didik saja, tetapi memiliki dampak positif terhadap guru. Guru memiliki strategi dalam menunjang tercapainya konsep manajemen pendidikan karakter. Strategi yang dapat menunjang seperti keteladanan, pembelajaran, pemberdayaan dan pembudayaan, pengatan, dan penilaian.

Para guru setidaknya memiliki karakter yang lebih baik lagi dari sebelumnya. Guru belajar menjadi sabar, teloransi, mampu memahami masalah, disiplin, dan memiliki integritas yang terpancar dari diri para guru MI Mafatihul Akhlaq Jepara. Dalam pelaksanaan program ini guru dituntut untuk kreatif dalam memilih strategi pemelajaran agar pendidikan karakter ini bisa tersampaikan dengan baik dan bisa bertahan lama dalam pembentukan karakter peserta didik. Pendidikan karakter ini merupakan tanggung jawab oleh seluruh warga sekolah terutama para guru. 
Pendidikan karakter harus dikembangkan setiap guru dalam proses pembelajaran, sehingga guru dituntut untuk menyusun perencanaan yang berbasis karakter. Dalam penilaian hasil belajar, semua guru harus mengukur kemampuan para siswanya dalam semua ranah, seperti ranah afektif terkait nilai-nilai karakter positif, kognitif, dan psikomotor. Penempatan pendidikan karakter diintegrasikan kepada semua mata pelajaran sehingga guru harus memiliki komitmen. Seperti guru memiliki silabus dan komponen kurikulum harus dikembangkan oleh setiap guru. Kurikulum merupakan komponen penting yang dijadikan acuan dalam penyelenggaraan pembelajaran (Ahsani, 2020).

Agar pembelajaran efektif terdapat beberapa syarat yang harus dipenuhi, yaitu (1) kejelian profesional para guru dalam mengantisipasi pemanfaatan berbagai kemungkinan arahan pengait yang harus dikerjakan oleh para siswa untuk menggiring terwujudnya kaitan-kaitan konspetual intra atau antar muatan pelajaran, dan (2) penguasaan material terhadap muatan pelajaran yang perlu dikaitkan. Berkaitan dengan pendidikan karakter sebagai pembelajaran yang terpadu dapat berupa pertanyaan atau tugas-tugas yang harus dikerjakan oleh para siswa yang mengarah kepada perkembangan pendidikan karakter peserta didik. Dampak lain diadakannya kegiatan ini yaitu terciptanya budaya madrasah yang baik sehingga mampu memperbaiki kinerja madrasah, baik kepala madrasah, guru, siswa, maupun warga madrasah lainnya. Situasi tersebut dapat terwujud melalui budaya madrasah yang bersifat sehat, solid, kuat, positif, dan profesional. Dengan demikian suasana kekeluargaan, kolaborasi, ketahanan belajar, semngat untuk terus maju, dorongan untuk bekerja keras dan belajar dapat diciptakan. Program ini juga memberikan dampak bagi orang tua atau wali murid. Budaya tersebut diharapkan mampu meningkatkan mutu MI Mafatihul Akhlaq Jepara. Sikap religius yang tampak dalam peserta didik merupakan wujud adanya pembiasaan kegiaatan keagamaan dan keteladanan dari kepala sekolah, guru dan juga lingkungan budaya yang baik. Penguatan Kegiatan keagamaan yang diterapkan dapat menumbuhkan kesadaran siswa dan juga menjadi habituasi siswa untuk senantiasa melaksanakan perbuatan baik berlandaskan oleh sang Pencipta.

\section{Simpulan}

Penanaman Pendidikan karakter yang ditanamkan di MI Mafatihul Akhlaq Jepara meliputi karakter religius, kejujuran, cerdas, dan peduli terhadap sesama Guru memiliki strategi dalam menunjang tercapainya konsep manajemen pendidikan karakter. Strategi yang dapat menunjang seperti keteladanan, pembelajaran, pemberdayaan dan pembudayaan, pengatan, dan penilaian. Model Pengajaran dan Implementasi Pendidikan karakter dalam menumbuhkan sikap religius peserta didik MI 
Elya Umi Hanik dan Eva Luthfi Fakhru Ahsani

Mafatihul Akhlaq Jepara dicontohkan dalam kegiatan sehari-hari antar guru seperti saling menolong antar guru dan peserta didik, menjalin hubungan baik antara guru dengan peserta didik maupun guru dengan guru dan sesama peserta didik. Peran Guru Madrasah dalam Mengembangkan Nilai Karakter diantaranya yang diterapkan di MI Mafatihul Akhlaq yaitu dalam proses pembelajaran, guru menyusun perencanaan yang berbasis karakter. Dalam penilaian hasil belajar, semua guru harus mengukur kemampuan para siswanya dalam semua ranah, seperti ranah afektif terkait nilai-nilai karakter positif, kognitif, dan psikomotor, adanya pembiasaan kegiatan keagamaan dan keteladanan guru menumbuhkan sikap religius pesreta didik.

\section{DAFTAR PUSTAKA}

Abbas, A., \& Muchlis, M. (2021). Strategy for Shapeing the Character of Students Based on PAI in School. 5(August), 867-877.

Ahsani, E. L. F. (2020). Analisis Bahan Ajar Kurikulum 2013 Berbasis Multiple Intelligence Kelas IV. ELEMENTARY: Islamic Teacher Journal, 8(1), 19-36. https://doi.org/http://dx.doi.org/10.21043/elementary.v8i1.7398

Amir, M. (2011). Rahasia Mengajar dengan Kreatif, Inspiratif, dan Cerdas. Logika Galileo.

Cahyani, D. I., Muna, F. U., Fadhilah, M. F., Wachidah, S., \& Hanik, E. U. (2021). Peran Lembaga Pendidikan dalam Membentuk Karakter Peserta Didik Era 4 . 0 di Sekolah Indonesia Kuala Lumpur. JEID: Journal of Educational Integration and Development, 1(3), 181-194.

Farida, I., \& Kamalia, A. A. (2020). KONSEP MANAJEMEN PENDIDIKAN KARAKTER DALAM MEMBENTUK AKHLAKUL KARIMAH DI MTs MA'ARIF NU KEMIRI. MANAGERE: Indonesian Journal of Educational Management, 2(1), 9-19. https://doi.org/10.52627/ijeam.v2i1.2

Hasibuan, A., Syah, D., Syarif, U. I. N., Jakarta, H., Sultan, U. I. N., \& Hasanuddin, M. (2018). Manajemen pendidikan karakter di sma.

Hefniy. (2017). MEMBANGUN PENDIDIKAN BERBASIS ISLAM NUSANTARA (Pendidikan Berbasis Karakter atau Akhlakul Karimah ?). Jurnal Islam Nusantara, $1(1), 27-35$.

Jamil, M., Mahmood, Z., \& Hussain, S. (2021). Content Analysis Of Social Studies Of Class $V$ With Reference To Character Education. 7(11), 149-152. https://doi.org/10.5281/zenodo.5671536

Koesoema, D. (2007). Pendidikan Karakter Strategi Mendidik Anak di Zaman Global. Grasindo. 
Koesoema, D. (2016). Pendidik Karakter Di Zaman Keblinger. Gramedia Widiasarana Indonesia.

Kusumawati, Naniek \& Maruti, E. S. (2019). Strategi Belajar Mengajar di Sekolah Dasar. CV. AE Media Grafika.

Nurafiati, S., Rahayu, T., \& Pramono, H. (2021). Strategy for Strengthening Character Education in Physical Education Learning at Makassar City Elementary Education Level. 48(6).

Rahayuningtyas, D. R., Rizqi, P. A., Putri, R. F. M., Sawwama, A., \& Ahsani, E. L. F. (2021). Peran Guru Dalam Mempertahankan Cultural Heritage Indonesia Dalam Membentuk Karakter Siswa di Sekolah Indonesia Kuala Lumpur. PENSA : Jurnal Pendidikan Dan Ilmu Sosial, 3(April), 27-37. https://doi.org/https://doi.org/10.36088/pensa.v3i1.1126

Rohman, T. (2019). Implementasi Manajemen Pendidikan Karakter dalam Pembinaan Akhlak Peserta Didik (p. 1).

Saifuddin, M. A., \& Hanik, E. U. (2020). Pembelajaran Daring Pemicu Degradasi Moral Pendidikan Di Era Pandemi Covid 19. Al Hikmah: Journal of Education, 1(2), 193-200.

Sani, R. A., \& Kadri, M. (2016). Pendidikan Karakter Mengembangkan Karakter Anak yang Islami. Pt Bumi Aksara.

Suhelayant, M. (2020). Manajemen Pendidikan. Yayasan Kita Menulis.

Sulistyowati, E. (2012). Implementasi Kurikulum Pendidikan Karakter. Citra Aji Parama.

Sultoni, A. (2013). DALAM MENGEMBANGKAN SIKAP RELIGIUS SISWA DI MADRASAH ALIYAH Achmad Sultoni (Universitas Negeri Malang ). 68-91.

Supadie, D. A. (2015). Pengantar Studi Islam. Rajawali Pers.

Zafi, A. A., Qulubana, A., Ahsani, E. L. F., \& Hanik, E. U. (2021). Meningkatkan Mutu Pendidikan Islam Di Mis Meningkatkan Mutu Pendidikan Islam Di Mis. AlIdaroh: Jurnal Studi Manajemen Pendidikan Islam, 5(2), 232-245. https://doi.org/https://doi.org/10.54437/alidaroh.v5i2.271

Zuhri, S., \& Usman, E. M. (2021). PENGARUH MEDIA SOSIAL DAN LINGKUNGAN SOSIAL sebagai proses menghasilkan satu. 2. 
